\title{
Tentative Analysis of Dong Biwu's Thought on the Rule of Law
}

\author{
Chunying Chen \\ The School of Philosophy \\ Zhongnan University of Economics and Law \\ Wuhan, China
}

\author{
Tianliang Nan \\ The School of Philosophy \\ Zhongnan University of Economics and Law \\ Wuhan, China
}

\begin{abstract}
Dong Biwu is one of pioneers and founders in new China to promote the rule of law. His thought on the rule of law has gone through a series of process from nascent stage to initial formation and to further development, which can stand the test of time and practice. However, due to historical background, traditional culture, social reality and other factors, his thought on the rule of law is strongly characterized by legal instrumentalism and does not completely free from the influence of the rule by man. This is an arduous task for his successors to continue to promote the rule of law and improve old-fashioned rule of law through reform. Therefore, this paper starts with the formation and main contents of his thought on the rule of law to explore and analyze the nature of his thought and its drawbacks in accordance with historical records from the perspective of his legislative ideology, judiciary ideology and guideline.
\end{abstract}

Keywords-Dong Biwu, Sun Yat-sen, thought on rule of law

\section{THEORETICAL BASIS FOR THE FORMATION OF DONG} BIWU'S THOUGHT ON THE RULE OF LAW

The formation of Dong Biwu's thought on the rule of law has gone through different stage of development and is influenced by various factors. Dong Biwu studied law in Japan in his early years, during which he met Mr. Sun Yat-sen for the first time and followed him to carry out revolution. Thus, his thought on the rule of law is deeply influenced by Mr. Sun Yat-sen. In addition, with the deepening of revolution, Dong Biwu gradually became a Marxist and realized that only socialism can save China, thus starting to learn the law philosophy of Marxism which has also profound influence on his thought. Of course, besides the above-mentioned factors, as a scholar in Qing dynasty, his thought on the rule of law is also affected by Chinese traditional culture.

\section{A. Sun Yat-sen's influence on Dong Biwu's thought on the rule of law}

Sun Yat-sen has scientific knowledge and understanding on many thoughts with great vision and the same is true of his thought on law. Dong Biwu was influenced by Sun Yat-sen when following him to join the revolution.

This project funded by the National Planning Office of Philosophy and Social Science in China "The philosophical interpretation of the harmonious coexistence between man and nature and the research on the development of ecological civilization in China "(NO.18VSJ013);

This project funded by the Medium and long term planning project in Zhongnan University of economics and law." Research on Marxist theory of ecological civilization and its contemporary value "(NO.ZN2017-01)
In Sun Yat-sen's view, the reason why Chinese society was so corrupt was because it lacked the rule of law and legal awareness. He pointed out that:"since the emperor of Qin conquered the six kingdoms, the central government established administrative system of prefectures and counties by undercutting aristocrats and landowner and burning of books and burying of scholars to gain direct administrative control over the peasantry. Past dynasties deemed the state as emperors' personal property, thus formulating legislation, as a precaution against people, to protect his own property. And the government was ignorant of general affairs related with people's well-being and livelihood. Thus the people had no measures to supervise government." Hence, it must govern a country in the light of the rule of law to change such situation. He advocated that: "there must be certain reasons for a country to sustain. The fundamental reason for democratic politics to sustain lies in the law and the pivotal organization of its operation rests with the congress. Only with shared laws abided by the whole nation can political measurements have rules to follow. Only with the free right of congress to exercise its power can the force of law be stable forever. This is the main significance of what we call the rule by man and the rule of law."

Dong Biwu's thought on the rule of law was deeply influenced by Sun Yat-sen. In Communism and the Three People's Principles, Dong Biwu expounded his views on new three people's principles and the laws it manifests. "The most important principles for Kuomintang's people's livelihood are nothing more than the following two aspects: one is equalization of land ownership, the other is regulation of capital. The gist of equalization of land ownership is to stipulate land law, land use act, land expropriation act and land tax act for the country. The labor law aimed at workers to improve their livelihood. The unemployed can seek poverty relief from the government." Dong Biwu emphasized that it should pay special attention to Sun Yat-sen's views, believing that new three people's principles of what Sun Yat-sen said was revolutionary three people's principles. Most importantly, Dong Biwu held that the ideal of the new three people's principles was the same with communism, which was trustworthy.

As time goes by, Dong Biwu found that in fact, China cannot be saved by only relying on bourgeoisie which was used by Mr. Sun Yat-sen. Only by mobilizing the masses can China be saved. Then with gradual understanding on 
Marxism-Leninism, Dong Biwu became a Marxist and his legal thoughts were also affected.

\section{B. Marxist legal theory is the cornerstone of Dong Biwu's thought on the rule of law}

While analyzing the failure of old democratic revolution in China, Dong Bi wu also studied the differences and similarities between the successful revolutions in the Soviet Union and the failure one in China. Through the comprehensive consideration on several aspects, he believed that it was the Leninist line that can guide China to march into real victory rather than Sun Yat-sen's line. Thus he embarked on communist path. The theories of Marx, Engels and Lenin on building a socialist country under the rule of law had great bearing on his thought on the rule of law.

First of all, with respect to socialist rule of law, Marx and Engels stated in German Ideology that 'this individual person can realize their own will in the form of law which, at the same time, free from any control from one of them." Lenin once said that "law will embody the will of whichever class holds the power of the state". And Dong Biwu stated that "in our socialist country, working class leads the masses to realize their own interests by state institutions which is built under the guidance of socialist rule of law." This statement shows that his thought on rule of law has closely relationship with the one of Marx.

Secondly, laws should be enacted right after taking the power of states. Lenin believed that "after taking the power of states, any class will change the original forms of ownership and out-dated constitutional system, so does the working class." After studying related theories, Dong Biwu based on the actual situation of China to expound his own views on law, believing that "it is natural to enact laws, decrees, regulations and rules after the establishment of new regime. It must enact new laws since we destroy old system, otherwise it is anarchism." At the beginning of People's Republic of China, Dong Biwu emphasized repeatedly to abolish old legal system and build new one suitable for the construction of new China.

What's more, it should act in accordance with the law after enacting laws. The Communist Manifesto illustrates that working class has the same interests with the whole proletariat and there is no conflicts in interests. However, such achievement must base on systematic rule of law, which requires our governing party to act in accordance with the law. Only by doing so can we help people to realize their own interests. With regard to "acting in accordance with the law", Dong Biwu also pointed out that 'the staff of parties and state organs must take the lead to observe national constitution, laws and regulations and set a good example for the masses. If they do not observe the laws they enact on their own, then the masses won't abide by the laws."

\section{Dong Biwu's thought on the rule of law is influenced by Chinese traditional culture}

Dong Biwu grew up in a family of intellectuals in which his father and uncle were both famous teachers in Hubei province. He read Confucian classics since childhood, later passed an examination held by the government and honored as a scholar in late Qing dynasty. So, his thought was profoundly influenced by traditional culture, including legal culture. And he inherited Chinese excellent traditional legal culture in a critical way, which was reflected as follows:

Many politicians and ideologists in ancient China also emphasized that the laws must be observed to attain people's trust, realizing the importance of laws in administering a country and governing the people. Shang Yang maintained in the Book of Lord Shang that emperors should attach importance to the rule of law. He stated that "a wise emperor should pay much more attention to the laws than benevolence and righteousness", "a wise emperor should take the law as the criterion and he should not listen to those who do not have the spirit of laws; nor promote those things which are not done in accordance with the law; nor do those things which are against the law. But you can debate with those who have legal awareness, promote those things which are done in the light of the law and do those things which observe the law." Han Feizi also pointed out that the laws must be observed to attain people's trust. He stated that "emperors may be in danger if the law is not observed and enforced strictly." Due to social nature and system then, it is difficult to put these thoughts into effect even someone propose such thoughts. But these thoughts still have far-reaching impact on next generations.

Dong Biwu also used an example from ancient Chinese culture which tells us that it should set a typical example to convince the public to elaborate this problem. He maintained that it should put the shoe on the right foot and do what you said. He held that if laws are not fully observed, then it is equal to not have laws. Such view was exercised in his own actual work. He believed that in the process of judicial adjudication, it must hear cases in accordance with laws, otherwise it will bring unnecessary troubles to the related parties and people will lost trust on the party, or even impairing the authority of laws.

\section{The MAin content of Dong Biwu's thought on the RULE OF LAW}

Dong Biwu devoted most of his life to the revolution, thus his thought on the rule of law integrates practices and theories. He made great contribution to our country's legislation, judiciary and law enforcement by using his own practical experience and theoretical basis.

\section{A. Legislative ideology--the premise to "promote the rule of law"}

Dong Biwu attached great importance to laws, hoping to formulate laws suitable for the people to make them live in accordance with the law and have rules to follow from the point view of workers and peasants.

1) The guideline of legislation---"political power belongs to the people"

Dong Biwu always regarded such guideline of "political power belonging to the people" as one of his benchmarks of thought on the rule of law. In his view, national political power belongs to the people and each of us, especially national party members and cadres should serve the people 
wholeheartedly. He pointed out that only by improving the system of National People's Congress can the people be the master of the country in its true sense. Political power belongs to the people, so does the laws, which should serve the people in turn. And only in the form of National People's Congress can this be achieved, which is the foundation of Dong Biwu's guideline of legislation.

From the point view of Dong Biwu, people can exercise their own interests into full play only through National People's Congress. He pointed out that National People's Congress had the right to formulate corresponding regulations and rules as soon as it was established and other regulations and rules enacted by other organs must be approved and recognized by National People's Congress before they finally went into effect. He also stated that people's government was merely an administrative body and must act in accordance with regulations and rules confirmed by National People's Congress, otherwise it was illegal. Of course, if people's government did those things that National People's Congress had yet to decide, then it was also illegal.

However, at the beginning of People's Republic of China, many leaders did not act in accordance with the law and convene National People's Congress in the light of related regulations and rules. Dong Biwu criticized such behavior. He pointed out in the first National People's Congress that many leaders and cadres didn't realize that national political power belonged to people and National People's Congress was the organ for people to exercise their rights, nor realize that only through National People's Congress can people's opinions and suggestions be gathered. They didn't realize the function of National People's Congress at all, not knowing that National People's Congress had the right to supervise the staff of state organs.

\section{2) Learning experience from other countries while basing} upon national situation

It cannot be achieved overnight to promote the rule of law. Socialist rule of law also experiences a process from initial stage to development stage then to gradual perfection in which Dong Biwu believed that it should first of all base on our national actual situation to promote the rule of law and then draw on successful experience from other socialist countries such as the Soviet Union. Only by doing so can the laws suitable for our national situation are formulated.

Firstly, it must base on the actual situation of our country to promote the rule of law while reflecting on our own experience. Dong Biwu strongly obeyed the ideology of dialectical materialism, persisted in pragmatism rather than formalism and advocated of establishment of legal system in our country on the basis of reality. He once drafted the guiding principles of national criminal procedures in person, together with other related workers, summarizing all criminal cases from high and intermediate people's court in 14 big cities throughout the country at that time. Based on this conclusion, he drew up the guiding principles of criminal procedures. And the current national criminal law and criminal procedures law initially came into being at this time. He also emphasized that socialist construction must keep the same pace with the promotion of the rule of law which must reflect new achievements of construction. In his view, the effort on the rule of law should be made from our actual situation in a flexible manner and cannot be done in a fixed model. In addition, it should take the national political and economic conditions into consideration to constantly perfect the rule of law.

Secondly, in the legislative process, our country should introduce advanced experience of other countries. Dong Biwu pointed out that with regard to advanced experience of other countries, we can learn from them in a bold way on the basis of our reality. Under such guideline, we learned the experience about the formulation of relevant legal documents from the Soviet Union such as law of marriage, criminal law, law of land, economic law, etc. to effectively develop our legislative work. As for the socialist legislation, we must adopt opened legislative system and actively and timely draw upon the experience from other countries and those conducive to legislative work in our history. Only on the basis of combining the previous experience, other countries' experience and our own reality can we really achieve the construction of legal system with socialist characteristics.

\section{B. Judiciary ideology--the process to "promote the rule of law"}

The ideology of people's judicature is another great contribution made by Dong Biwu to promote the rule of law in China. He distinguished new legal system from old one in China in his judiciary ideology, clarifying the direction of development for new legal construction in our country. The main contents of his people's judicature are as follows:

First of all, to improve ideological level is the prerequisite for the perfection of people's judicature. We need to discard old judiciary system which reflects the interests of exploiting class. And this process is in nature the one to refresh people's ideology. Additionally, Dong Biwu also believed that it should made great efforts on people's cultural concept to change the dependence on old judiciary system if we want to promote our own judiciary ideology.

Furthermore, people's judicature is to safeguard their democratic rights. From the point view of Dong Biwu, whether people's democratic rights are safeguarded or not is one of the criteria to distinguish between the new and old judicature. He believed that with the continuous improvement of democratic system and legal system, people's democratic rights should also be safeguarded in a more effective way. In the stage of socialist construction, we can protect people's legitimate rights and interests and punish severely those who violate people's democratic rights through judicature.

Lastly, construction of judiciary team. In Dong Biwu's view, the key to construct judiciary team is its personnel. Judicial personnel must serve the people wholeheartedly in accordance with the requirements of the party and the people. He expressed that judicial officials are the key in the construction of judiciary team. And he also put forward lots of methods to cultivate judicial officials to solve the actual situation of insufficient officials at the beginning of new China. 


\section{The ideology of law enforcement--the keypart of "legal construction"}

Law-based administration is one of the contents of Dong Biwu's thought on the rule of law. Law-based administration means that under the leadership of governing party, all state organs of political power and its officials use laws and its systems to govern a country and society

In the 8th National Congress of the Communist Party of China, Dong Biwu stated that the ideology of people's democratic rule of law reflected by state institutions was the fundamental method to achieve people's democratic dictatorship. On this basis, he believed that the important means for people's democratic rule of law was to act in accordance with the law and presented its significances.

On the one hand, there must be laws to go by. Dong Biwu pointed out that only with perfect legal system can we really had laws to go by. In order to perfect our country's laws and regulations quickly, he participated in the formulation of a series of laws and regulations. In 1978, under his leadership, the legislation culminated for the first time on the work of the rule of law in China. The formulation of a series of laws and regulations paved the way for Dong Biwu's thought on the law-based governance.

On the other hand, the laws must be observed. As long as it is stipulated by laws, it must be carried out in accordance with provisions and severely punish those who break laws. And as for those who violate laws on purpose, it must be dealt with according to relevant stipulations, no matter how much contributions he made for the country in the past and no matter how high social status he is now. With respect to those who do not know laws, it should actively conduct conducive education on them. In brief, we need to eliminate those phenomena and behaviors of despising and breaking laws.

\section{THE DRAWBACKS OF DONG BIWU'S THOUGHT ON THE RULE OF LAW}

Dong Biwu is the only one of the first generation of national leaders in our country to study the law. Although he made enduring contribution to promote the rule of law, there still exist drawbacks in his thought on the rule of law due to the limitation of the times.

\section{A. Relative weak foundation of legal knowledge}

Dong Biwu was deeply influenced by feudalism in his early years but later followed Sun Yat-sen after waking up to fatuous feudal dynasty. During this period, he studied laws in private Japanese university, but he hardly focused on his study since he studied abroad as a refugee for each time. Therefore, his knowledge on the law was not as comprehensive as he expected.

\section{B. Dong Biwu's unsystematic thought on the rule of law}

Dong Biwu elaborated his thought on the rule of law mostly in relevant speeches to work conferences rather than in specific books. He didn't summarize his thought in a systematic way, so his thought on the rule of law did not come into being as a systematic way. His thought on the rule of law was summarized and extracted by later scholars from his speeches or letters.

\section{Distinct feature of class struggle in his ideology of people's judicature due to the influence of the times}

After the founding of new China, counter-revolutionists were mostly annihilated, but there was still some residual force. Moreover, incorrect judgment on revolutionary situation occurred, which emphasized to tell friends and enemies apart and severely cracked down on reactionists to consolidate its political power. Under such situation, Dong Biwu came up with such opinions as that "people's judicature is the weapon to consolidate people's democratic dictatorship" and "people's court must distinguish between two kinds of contradictions in a rigorous way, which highlighted the service of judiciary on the class struggle. However, we have basically eliminated class and class contradiction is not our principal contradiction any more, thus what Dong Biwu did in the past with his thought on the rule of law is not suitable for the current situation.

\section{CONCLUSION}

Dong Biwu's thought on the rule of law was profoundly influenced by Marxism, Mr. Sun Yat-sen and Chinese traditional culture. He promoted the socialist ideology on the rule of law characterized by "political power belonging to the people, learning experience from other countries, perfecting people's judicature and persisting in impartial law enforcement" in the process of Chinese revolution and construction by combining theories and practices and through learning experience from western countries, which makes indelible contribution to socialist legal construction with Chinese characteristics. Of course, due to the limitation of historical condition and practical environment, there is still room to improve his thought on the rule of law and his theory and effectiveness have yet to be enhanced by later generations.

\section{REFERENCES}

[1] Editorial group of the collected works of Dong Biwu. Dong Biwu Political and Legal Collected Works [M]. Beijing: Law Press, 1986

[2] Editorial group of the collected legal works of Dong Biwu. Dong Biwu Legal Collected Works [M]. Beijing: Law Press, 2001.

[3] Ed itorial group of selected works of Dong Biwu. Dong Biwu's Selected Works[M]. Beijing: People's Publishing House, 1985

[4] Marx, Engels. Karl Marx and Frederick Engels (Volume 3)[M]. Beijing: People's Publishing House, 1960

[5] Lenin. Len in Collected Works(volume 16, 2nd edition)[M]. Beijing: People's Publishing House, 1988.

[6] Sun Wanzhong, Liu Ruichuan. Dong Biwu Collected Works of the Rule of Law[M]. Beijing: People's Court Press, 2004

[7] Sun Wanzhong, Ying Yong. Dong Biwu Collected Works of the Rule of Law[M]. Beijing: People's Court Press, 2008

[8] Li Yuanben. A Tentative Probe into Dong Biwu's Thought on the Legislative Administration[J]. Journal of Zunyi Normal College, 2001(4).

[9] Ke Xinfan. Review for Historical Status of Dong Biwu's Legal Thought[J]. Journal of Anyang Teachers Colleges, 2006

[10] Zhang Hongxiang. General Introduction of Dong Biwu's Thought on the Rule of Law[J]. Journal of Huaiy in Teachers College(Social sciences Edition), 2000(2). 